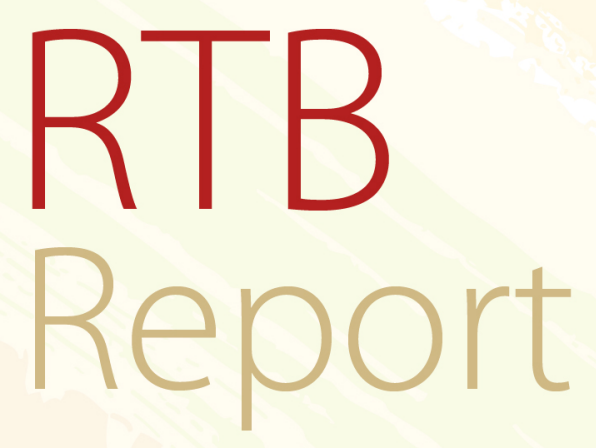

Current status of knowledge about end-user preferences for boiled potato in Uganda A food science, gender and demand perspective

Sarah Kisakye, Edgar Tinyiro, Sarah

Mayanja, and Diego Naziri

$\begin{array}{llllllllllll}N & O & V & E & M & B & E & R & 2 & 0 & 2 & 0\end{array}$ 


\section{RTB Report}

Current status of knowledge about end-user preferences for boiled potato in Uganda A food science, gender and demand perspective

\section{Published by the CGIAR Research Program on Roots, Tubers and Bananas}

The CGIAR Research Program on Roots, Tubers and Bananas (RTB) is a partnership collaboration led by the International Potato Center implemented jointly with the Alliance of Bioversity International and the International Center for Tropical Agriculture (CIAT), the International Institute of Tropical Agriculture (IITA), and the Centre de Coopération Internationale en Recherche Agronomique pour le Développement (CIRAD), that includes a growing number of research and development partners. RTB brings together research on its mandate crops: bananas and plantains, cassava, potato, sweetpotato, yams, and minor roots and tubers, to improve nutrition and food security and foster greater gender equity especially among some of the world's poorest and most vulnerable populations.

www.rtb.cgiar.org/

\section{Contact:}

RTB Program Management Unit International Potato Center (CIP)

Apartado 1558, Lima 12, Peru

rtb@cgiar.org・www.rtb.cgiar.org

ISBN: 978-92-9060-554-6

DOI: 10.4160/9789290605546

Correct citation: Kisakye, S., Tinyiro, E., Mayanja, S., and Naziri, D. (2020). Current status of knowledge about end-user preferences for boiled potato in Uganda - A food science, gender and demand perspective. CGIAR Research Program on Roots, Tubers and Banana (RTB), International Potato Center (CIP): Kampala, Uganda.

\section{November 2020}

(C) International Potato Center on behalf of RTB 


\section{Current status of knowledge about end-user preferences for boiled potato in Uganda - A food science, gender and demand perspective}

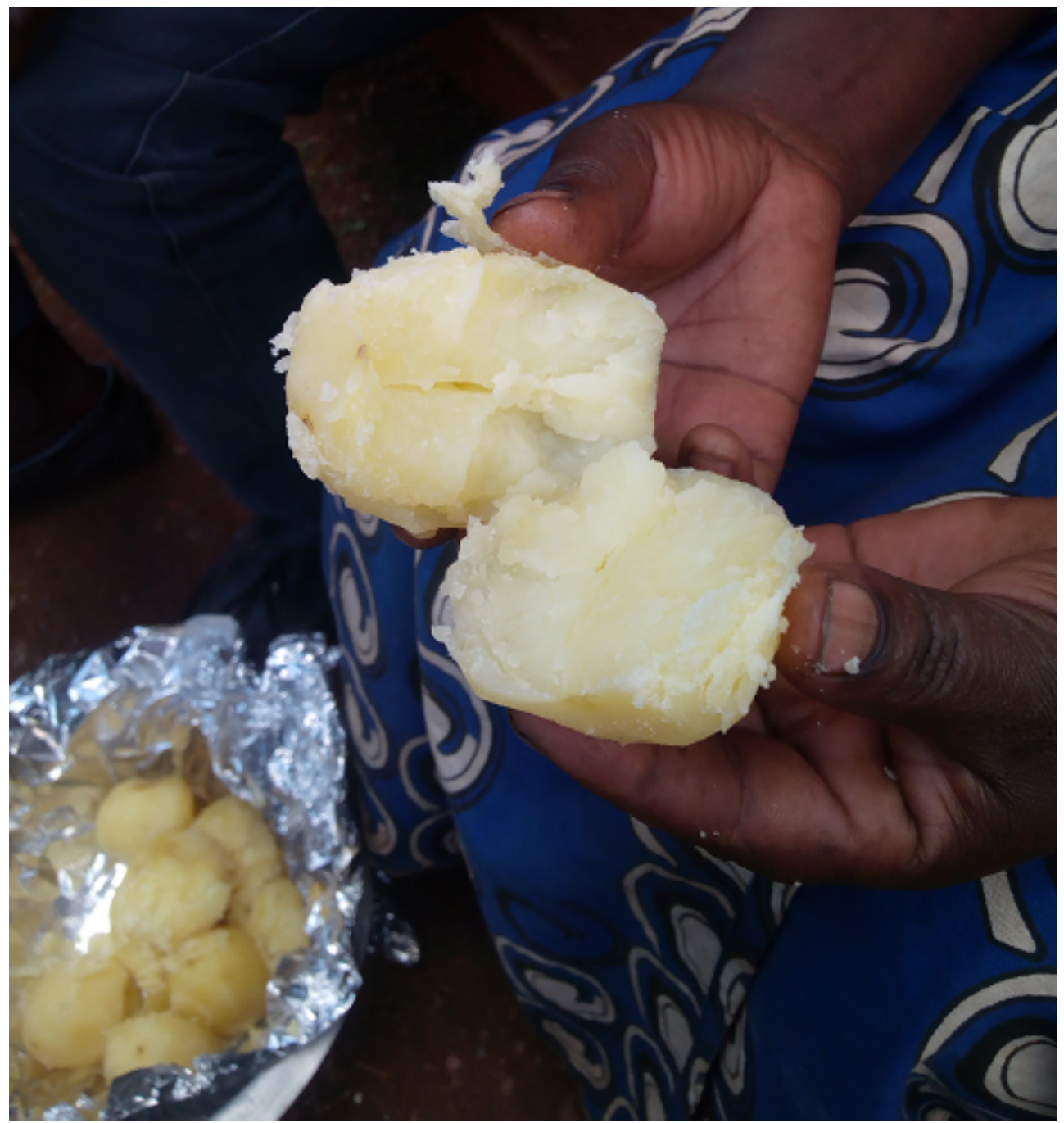

Sarah Kisakye, Consultant, National Agricultural Research Organization (Kawanda)

Samuel Edgar Tinyiro, Consultant, National Agricultural Research Organization (Kawanda)

Sarah Mayanja, International Potato Center

Diego Naziri, International Potato Center 


\section{Acknowledgments}

This study was implemented and funded by the CGIAR Research Program on Roots, Tubers and Banana (RTB CC4.1). A methodology similar to the one developed by the RTBFoods project was adopted and the findings complement the work conducted under RTBFoods. 


\section{Table of Contents}

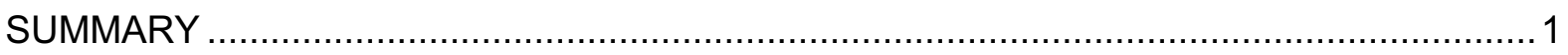

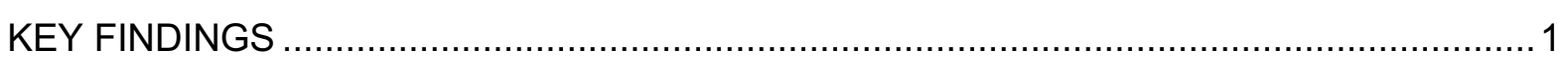

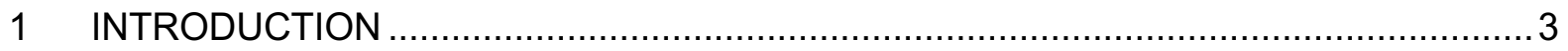

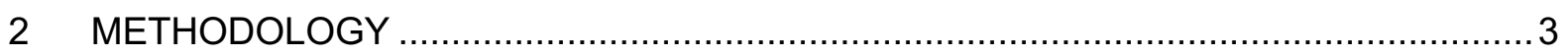

3 SECTION I: FOOD SCIENCE …...................................................................... 4

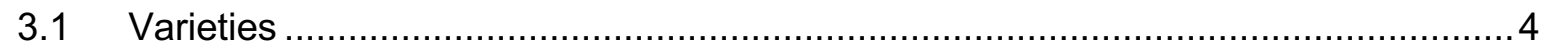

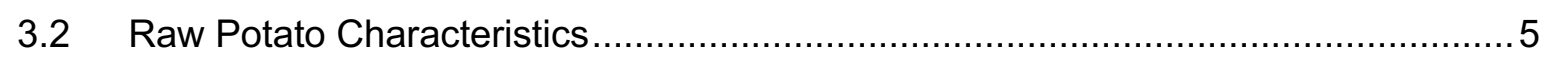

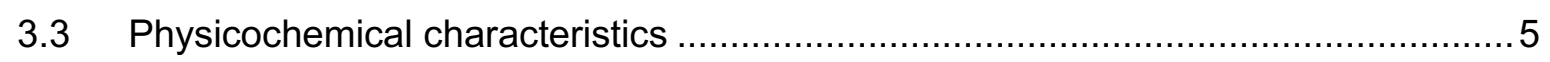

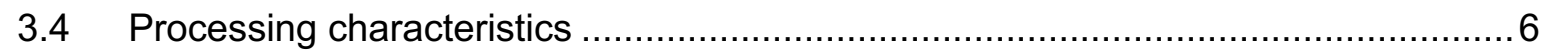

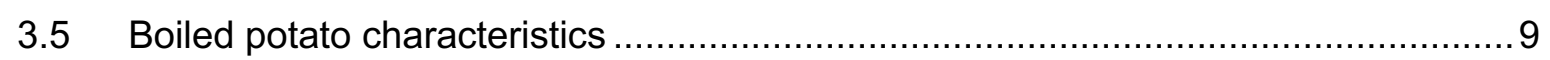

4 SECTION II: GENDER AND SOCIO-CULTURAL CONTEXT .................................... 10

4.1 Agronomic norms and practices of potato in different regions of Uganda .............. 10

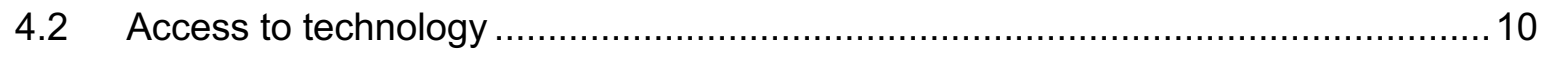

4.3 Farmer access to and adoption of new potato varieties.................................. 11

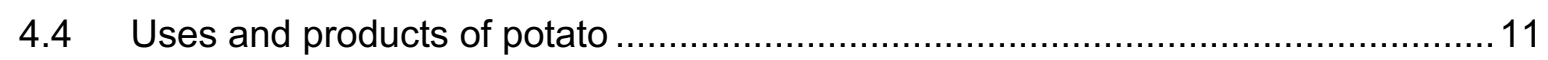

4.5 Gender dimensions of the boiled potato value chain ............................................. 12

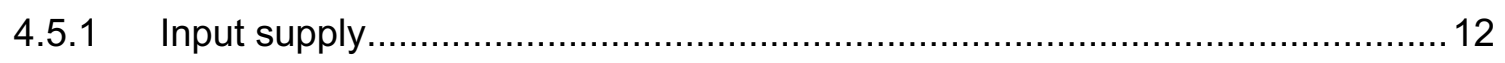

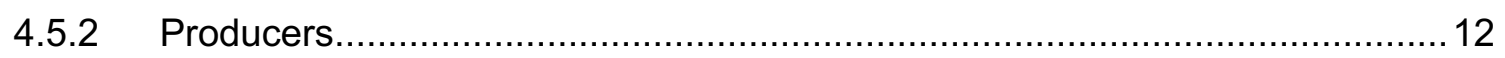

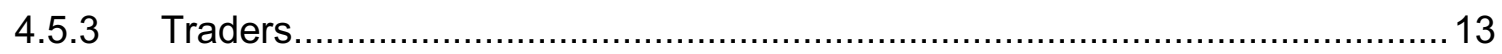

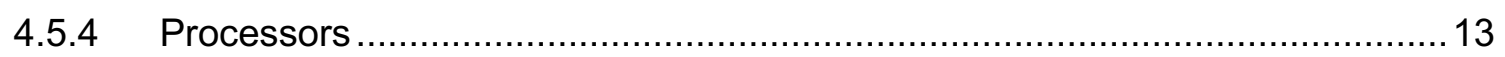

4.6 Trade-offs between different uses of potato and policy issues ........................... 14

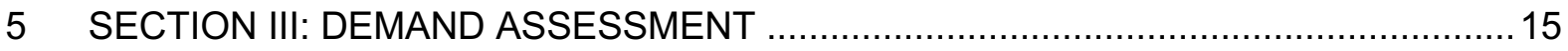

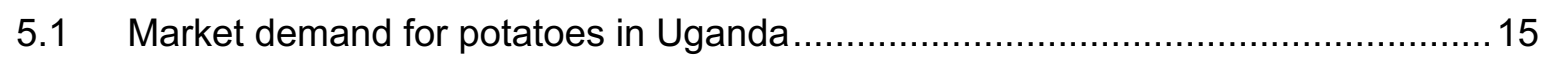

5.2 Value chain actors and demand trends....................................................... 15

5.2.1 Size of the different value chains and trends ............................................. 16

5.2.2 Geographical and demographic characteristics of the value chain actors ........16

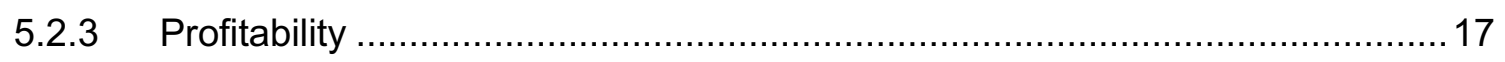

5.3 Preferred characteristics of potato by the different value chain actors ................... 17

5.4 Transportation, storage and sale of the potato product ...................................... 19

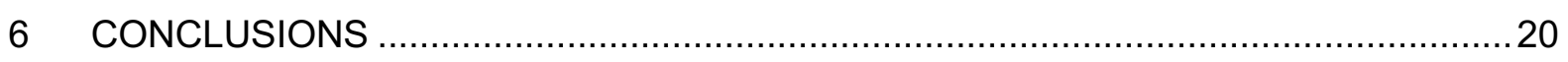

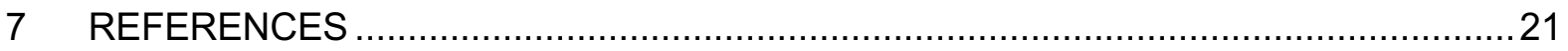

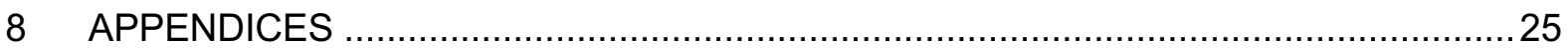

8.1 APPENDIX A: OVERVIEW TABLE OF THE POTATO VALUE CHAIN AND PREFERRED CHARACTERISTICS ................................................................. 25

8.2 APPENDIX B: MAJOR POTATO GROWING DISTRICTS IN UGANDA ...............27 


\section{List of Tables}

Table 1 Sensory, post-harvest and morphological attributes of selected potato varieties grown in Uganda

Table 2 Good raw potato characteristics 6

Table 3 Physicochemical characteristics of selected potato varieties released in Uganda ...6

Table 4 Good characteristics of potato at each processing step for boiled potato product .... 8

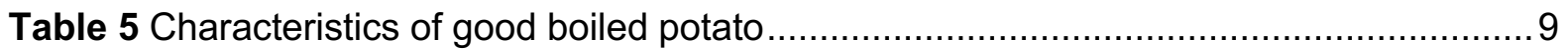

Table 6 Size of value chains in urban and peri-urban markets according to the Klls ...........16

Table 7 Preferred characteristics for potato per value chain actor according to the KIls...... 18

\section{List of Figures}

Figure 1 Priority potato varieties in Kigezi Highlands (South western Uganda) ................... 4

Figure 2 Preparation of boiled potato and related products ........................................... 


\section{SUMMARY}

This report synthetizes the current state of knowledge about preferred characteristics for boiled potato among the different value chain actors; demand and profitability for the product in urban and peri-urban areas; and the agronomic practices and gender norms surrounding the potato product in Uganda. A literature review as well as key informant interviews were conducted to obtain information. From the findings, preferred physicochemical characteristics of raw and boiled potato are centered on appearance, color, size, texture and dry matter content. This can inform a more demand-oriented breeding by CIP and national partners. Potato is important for food and income generation for both men and women value chain actors, hence new potato varieties have been adopted in the different regions of Uganda. Across the value chain, the potato product has been found to be highly profitable.

\section{KEY FINDINGS}

- Preferred raw potato characteristics by producers, traders and consumers include red skin color, yellow flesh color, smooth skin and big size tubers.

- Processors prefer; white/cream flesh color, medium to large size, shallow eye depth, smooth skin and high dry matter content.

- High dry matter content $(\geq 20 \%)$ and low reducing sugars $(\leq 3 \mathrm{mg} / \mathrm{g})$ are physicochemical characteristics that translate into desirable boiled potatoes for processors and consumers.

- Good boiled potato characteristics include; floury texture (mealy), not mashy, good taste, bright yellow color, and good potato smell.

- Potato is an important food and income generating crop grown by women and men farmers in Uganda.

- New potato varieties have been introduced and adopted in Uganda, albeit at varying scales in the growing regions. Popular varieties include Rwangume, Victoria and Kinigi.

- Resource constrained households are still opting for local landraces such as Byumba.

- There are demarcated gender division of roles in production, marketing and processing of boiled potato.

- Women are responsible for seed conservation especially in subsistence production.

- Commercial seed production is the realm of men given the capital outlay required.

- Women dominate in small scale retailing and processing of potato.

- The level of potato marketing and domestic demand of potato products in Uganda is on the increase.

- Potato supply chain commonly ends in almost all the urban markets and restaurants in Uganda.

- Key players along the ware potato value chains include farmers, agents (or brokers), local traders, urban wholesalers, urban retailers, processors, consumers, and institutions.

- Within production areas, processors provide the smallest market outlet for ware potatoes across all of the districts.

- In urban areas, hotels, restaurants and take-aways (fast-food outlets) are the main business enterprises that process potatoes hence providing a large market for the traders of fresh potatoes.

- Urban wholesalers and travelling traders mainly come from towns near the production areas and Kampala districts.

- The potato value chain comprises of people across regions, ethnic groups and religions.

- Potatoes are sold fresh and commonly consumed in boiled, fried, chips or crisps form. 
- High transport costs and lack of organized storage make it difficult for value chain actors to successfully market their produce.

- Potatoes flow through a multi-staged marketing channel i.e. through a few different value chain actors before reaching the final consumer hence profits are shared by many players along the chain. 


\section{INTRODUCTION}

Potato is the fourth most important food crop in the world in terms of production with 388 million tons produced in 2017, following rice, wheat and maize (FAOSTAT, 2019). In East Africa, Uganda is the 3rd largest producer of potatoes after Rwanda and Kenya, and its higher altitude areas are well placed to benefit from the growing demand for potato products in the region. Not only is potato an important crop for food and income generation but it is also one of the 16 major food crops prioritized by the Government of Uganda (UBOS, 2018). Due to growing demand, potato has been identified by Uganda's Ministry of Agriculture, Animal Industry and Fisheries (MAAIF) in its development strategy and investment plan as a priority crop for strategic intervention. (UBOS and MAAIF, 2011)

The report is divided into 3 sections - I. Food science, II. Gender and socio-cultural context, and III. Demand-assessment. Food research studies in Africa have for a long time put emphasis on physicochemical, nutritional and safety aspects of food while making minimal consideration for sensory preferences of consumers. (Rakotosamimanana and De Kock, 2020). In light of this, the main objective of the food science section is to provide insight and understanding of the current status of research related to end-user preferred sensory characteristics of raw and boiled potato via a value chain approach. This will set the foundation to guide subsequent field studies on food preferences disaggregated by gender and specific value chain end users such as producers, processors, traders and consumers. The section on gender and socio-cultural context focuses on the potato agronomic practices and associated norms in Uganda; the new varieties associated with boiled potato which have been introduced in the country; and whether there is expertise or evidence about the factors influencing adoption in this context. It reveals the main and the alternative uses of potato; the gender dimensions in the potato value chain; and the trade-offs between different uses of potato and how these affect different groups of people regarding their participation, workload and benefit from boiled potato. The demand assessment enlightens on the potato value chain, size of the different demand segments and general demand for potato in Uganda's urban and peri-urban areas. It also provides information on geographical and demographic characteristics of the different value chain actors, and their preferred potato characteristics.

\section{METHODOLOGY}

A desk study was conducted to identify and analyze relevant literature on the end-user preferred sensory characteristics of raw and boiled potato; gender roles; the potato value chain and demand in urban and peri-urban areas of Uganda. For validation purposes, key informant interviews were conducted, not only to obtain information on important quality characteristics of boiled potato at different stages from raw, during preparation and at consumption, but also to obtain information on demand and profitability of the potato product. Key informants were purposively selected and these included food scientists, breeders and experienced potato traders. Female respondents with experience in boiled potato preparation and consumption were also interviewed because they are the ones mostly involved in food preparation. Some interviews were conducted at National Agricultural Research Laboratories, Kawanda, while others were conducted in market areas. The gender and socio-cultural section is based on general knowledge on the role of women and men in potato production and marketing in Uganda, and Sub Saharan Africa at large. The Gender Dimensions Framework (Rubin et al., 2009) was used to structure and analyze information obtained from various resources related to gender and the socio-cultural context for boiled potato in Uganda. This report also draws on findings from previous State of Knowledge reports developed in Uganda and West Africa, which focused on both boiled and fried sweetpotato. 


\section{SECTION I: FOOD SCIENCE}

\subsection{Varieties}

South western and Eastern region represent the leading production areas for potato in Uganda, however potato is also grown in West Nile, Central and Western Uganda (Sebatta et al., 2014; IFDC, 2017). Rwangume (NAROPOT 4), Victoria and Kinigi predominate in the Kigezi sub-region (South western Uganda) (Fig. 1). Other varieties in this region include Rwashaki, Mumba, Sutama, Kimuli, Rutuku, Cruza, Mitare and Kachpot 1 (Mbowa and Mwesigye, 2016).
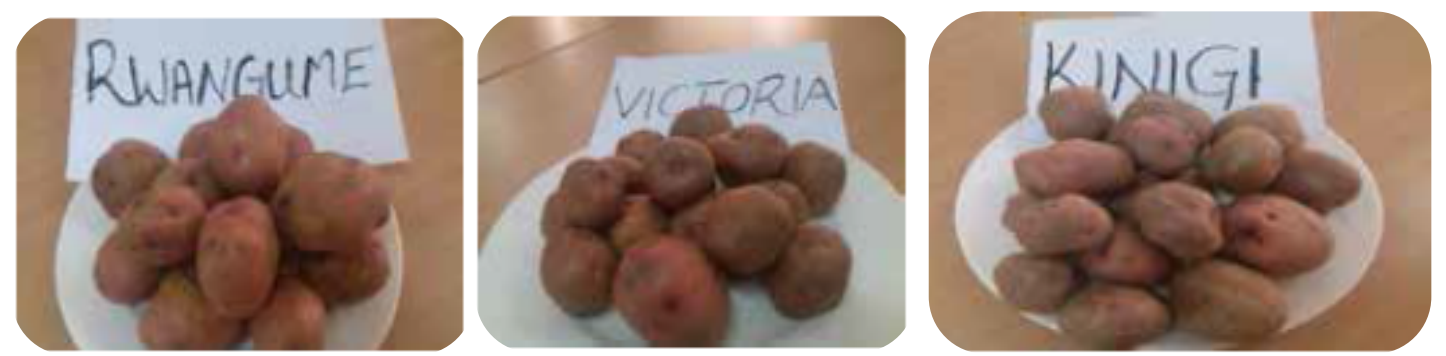

Figure 1 Priority potato varieties in Kigezi Highlands (South western Uganda)

(Source: PASIC, 2015)

Kabale red, Victoria and Wanale are the leading potato varieties grown in Eastern Uganda. Other varieties are; Rwangume, Nakpot 1, Sankena, Civilian, Megabond, Cruza and Kachpot 1 (Tatwangire and Nabukeera, 2017). According to Namugga et al. (2017), Rwangume and Victoria are the commonly grown varieties in South Western, Eastern and Central regions. A list of selected potato varieties with their sensory, post-harvest and morphological attributes is shown in Table 1.

Table 1 Sensory, post-harvest and morphological attributes of selected potato varieties grown in Uganda

\begin{tabular}{|l|l|l|l|l|l|l|l|l|}
\hline $\begin{array}{l}\text { Variety Name/ } \\
\text { Characteristic }\end{array}$ & Rutuku & Cruza & Sangema & Victoria & Kisoro & Kabale & $\begin{array}{l}\text { Nakpot } \\
\mathbf{1} \text { to 5 }\end{array}$ & $\begin{array}{l}\text { Kachpot } \\
\mathbf{1} \text { and 2 }\end{array}$ \\
\hline Tuber size & Large & Large & Medium & Large & Medium & Large & $\begin{array}{l}\text { Medium } \\
\text { - large }\end{array}$ & Medium \\
\hline Skin color & $\begin{array}{l}\text { Light } \\
\text { red }\end{array}$ & $\begin{array}{l}\text { White } \\
\text { mottle }\end{array}$ & Pink & Red & White & $\begin{array}{l}\text { Purple } \\
\text { mottled }\end{array}$ & $\begin{array}{l}\text { White, } \\
\text { rose } \\
\text { red, red }\end{array}$ & $\begin{array}{l}\text { Red, } \\
\text { white }\end{array}$ \\
\hline Flesh color & Cream & $\begin{array}{l}\text { White } \\
\text { ringed }\end{array}$ & Yellow & $\begin{array}{l}\text { Light } \\
\text { cream }\end{array}$ & Cream & White & $\begin{array}{l}\text { White, } \\
\text { cream }\end{array}$ & Cream \\
\hline Tuber shape & $\begin{array}{l}\text { Oval } \\
\text { round }\end{array}$ & Oval & Oval long & Round & $\begin{array}{l}\text { Oval } \\
\text { large }\end{array}$ & Round & $\begin{array}{l}\text { Oval } \\
\text { long, } \\
\text { round, } \\
\text { oval }\end{array}$ & Round \\
\hline Storability & Good & Fair & Good & Good & Good & Excellent & Good & Good \\
\hline
\end{tabular}

Source: Tindimubona et al. (2014); NARO (2017) 
More recently, a number of improved varieties imported from the Netherlands have been released, namely Arizona, El Mundo, Sagitta, Markies, Connect, Sarpomira and Voyager (NARO, 2017).

\subsection{Raw Potato Characteristics}

Preferred characteristics of raw potato tubers vary among different end-users and regions however, they are largely interlinked. Agronomic and economic attributes such as high yield, early maturity, disease resistance and, crucially, market demand (traders and consumers) usually inform farmers' decisions about varietal selection. Consumers are reported to prefer red over white skin color, good taste and big size tubers. In parts of Eastern Uganda (Kapchorwa), key varietal attributes according to farmers include: storability, high dry matter and flesh color while in South Western Uganda (Kabale and Kisoro) it was tuber size (CIP, 2018). According to Namugga et al. (2017), preferred attributes by farmers include red skinned and yellow fleshed potatoes which are associated with good eating quality. Katundu et al. (2010) reported that consumers look out for potatoes with smooth skin, no sprouting, no blemishes and no greening when purchasing at the marketplace.

On the contrary, small size tubers were identified as one of several characteristics leading to abandoning certain varieties such as Bumbamagara and Cruza (Wachira et al., 2008). Namugga et al. (2017) reported that Cruza and Marierahinda were increasingly rejected in all major potato growing regions due to their white skin, low marketability and, in the case of Cruza, development of a mashy texture when cooked. Potato farmers in Eastern Uganda sort out poor-quality potatoes on the basis of size (small), physical damage (cuts and bruises), greening of tubers and off-type varieties (Tatwangire and Nabukeera, 2017).

Among traders engaged in grading of potatoes prior to sale in South Western Uganda, some of the criteria used include: variety, skin and flesh color, tuber size, maturity level, water content and damage (Bonabana-Wabbi et al., 2013; Mbowa and Mwesigye, 2016). The market is a key driver of preference trends where red skinned varieties are preferred over white despite color and quality traits not being correlated (Wachira et al., 2008). Kachpot 5 is reported to be a high yielding variety preferred for its shape by processors and yet, farmers do not like it because of its white skin color (FAO, 2015). Victoria is preferred by traders and consumers in this region because of longer storability, good cooking properties and red skin color. In addition, traders prefer varieties which have heavy tubers, good mashing and taste attributes (Tatwangire and Nabukeera, 2017). Similarly, in a report by Sikuku and Ogemah (2005), Victoria was reported to be the most popular improved variety in Eastern Uganda, and this was attributed to the consumer-preferred red skin color. Susceptibility to post-harvest degradation is also an important varietal attribute. As reported by Tatwangire and Nabukeera (2017), Sebei, Singo and Mbale are more prone to post-harvest deterioration compared to Kenya, Kisoro and Wanale. Desirable characteristics of fresh/raw potato from Key Informant Interviews (KIls) are summarized in Table 2.

\subsection{Physicochemical characteristics}

Regarding physicochemical properties, potatoes which are high in dry matter content $(\geq 20 \%)$ and low in reducing sugars $(\leq 3 \mathrm{mg} / \mathrm{g}$ ) provide desirable sensory properties for processing and consumption (Katundu et al., 2007; Abong et al., 2009; Pedreschi, 2012). Physicochemical properties of selected varieties are shown in Table 3.

Kinigi and NAROPOT 3 were the varieties reported to have the highest dry matter content (Muhumuza et al., 2020). A previous study by Nuwamanya et al. (2011) reported relatively higher dry matter content for three potato varieties; Kinigi $(28.4 \%)$, Victoria $(28.3 \%)$ and Kachpot (30.5\%). Starch is a major component of dry matter, constituting 65-80\% (Pedreschi, 2012). Furthermore, according to Nuwamanya et al. (2011), increased firmness of roots, tubers and cereals is associated with high amylose starch content. This could impact on the texture of boiled potato. More so, potatoes with high starch content are associated with a 
desirable floury texture (Katundu et al., 2007). High reducing sugar content in potatoes instigates the undesirable non-enzymatic browning caused by the Maillard reaction especially during frying (Pedreschi, 2012). In addition, high total sugar content (>12.5 g/kg) gives potatoes an undesirable sweet taste and soggy texture (Katundu et al., 2007)

Table 2 Good raw potato characteristics

\begin{tabular}{|l|l|}
\hline Characteristic & Description \\
\hline Tuber form/general appearance & $\bullet$ No physical damage \\
& $\bullet$ Smooth skin \\
& $\bullet$ Has few buds/eyes \\
\hline Tuber size & $\bullet$ Big size tubers \\
\hline Color & $\bullet$ Dirty brown peel color - pale yellowish flesh \\
& $\bullet$ No discolored patches \\
& $\bullet$ Creamy flesh color \\
& $\bullet$ White for mashed potatoes, yellow for chips \\
\hline Texture & $\bullet$ Hard/Firm \\
\hline Smell & $\bullet$ Smells fresh \\
& $\bullet$ Odorless \\
\hline
\end{tabular}

Table 3 Physicochemical characteristics of selected potato varieties released in Uganda

\begin{tabular}{|l|c|c|c|}
\hline Variety & $\begin{array}{c}\text { Dry Matter Content } \\
(\mathbf{\%})\end{array}$ & $\begin{array}{c}\text { Reducing Sugars } \\
\text { (mg/g) }\end{array}$ & $\begin{array}{c}\text { Average Tuber } \\
\text { Weight (g) }\end{array}$ \\
\hline Rutuku & 17.2 & 5.8 & 109.9 \\
\hline Cruza & 19.5 & 2.4 & 61.8 \\
\hline Rwangume & 17.7 & 6.6 & 68.8 \\
\hline Kinigi & 20.3 & 2.6 & 87.4 \\
\hline Rwashaki & 19.2 & 2.1 & 80.7 \\
\hline NAROPOT 1 & 18.4 & 1.9 & 89.1 \\
\hline NAROPOT 3 & 20.6 & 2.1 & 101.0 \\
\hline NAKPOT 1 & 19.7 & 4.8 & 77.2 \\
\hline NAKPOT 5 & 18.9 & 3.1 & \\
\hline
\end{tabular}

Source: Muhumuza et al., (2020)

\subsection{Processing characteristics}

In Uganda, ware potato is mainly consumed as a boiled vegetable and is widely processed as shown in Fig. 2. Processed products from potato include; chips, fried or grilled, crisps, mashed and mixed sauce (local name 'katogo') (Tesfaye et al., 2010; CIP, 2018). 


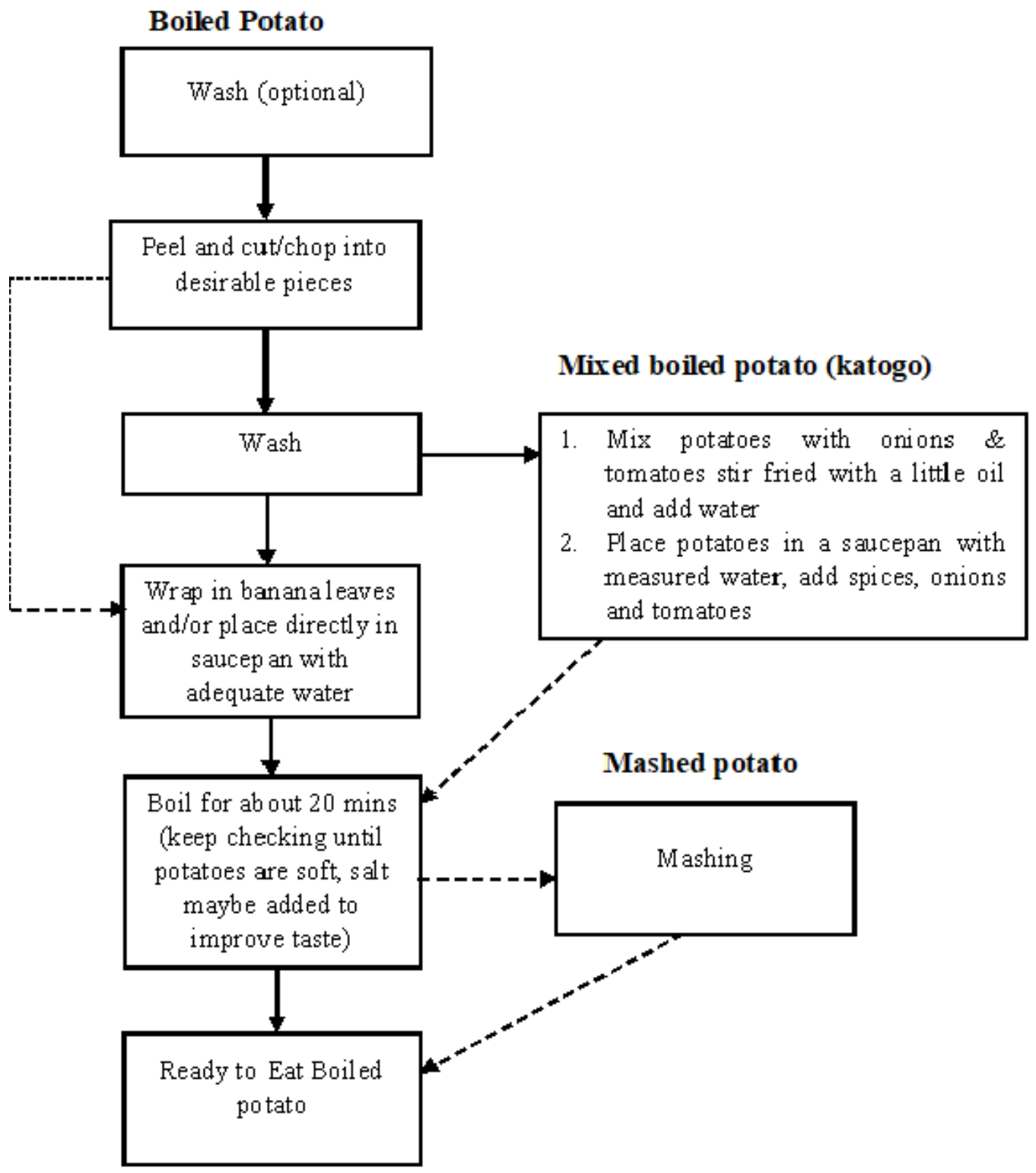

Figure 2 Preparation of boiled potato and related products

Generally, processing of potato into value added products is still minimal, due to some constraints such as fluctuating prices, low quality of ware potato and inadequate capital (FAO 2015). Low quality of potatoes encompasses immature tubers, thick skin, deep eyes, inconsistency in tuber sizes and varieties, cuts and bruises due to poor harvest and postharvest practices (Tatwangire and Nabukeera, 2017). More recently, processing into chips and crisps is gaining traction in response to growing demand from urban population, fast food restaurants and schools among others (Aliguma et al., 2007; CIP, 2018). Important quality attributes for potato chip processors in descending order include: high dry matter content, smooth skin, shallow eye depth, medium to large size and white/cream flesh color. Varieties associated with these attributes include: Kachpot 1, Kachpot 2, Rutuku, Nakpot 1 and Nakpot 5. In Kampala and Eastern Uganda, the preferred varieties for processors in descending order are: Victoria, Mbale, Singo, Kisoro, Kapchorwa, Wanale and Kabale red (Tatwangire and Nabukeera, 2017). In addition, they reported that preferred characteristics by processors were big size of tubers, easy to process and good for chips. Mbowa and Mwesigye (2016) also reported that Rwangume, Kinigi and Kachpot 1 are among the most preferred varieties by processors because of their big size. Quality losses along the post-harvest and marketing 
chain are mostly related to potato tubers which are; rotten, cut, bruised, greened, soft and sprouted (CIP, 2018). The Cruza variety is reportedly unsuitable for chips processing due to coloration of the vascular ring during frying (Wachira et al., 2008). Mbowa and Mwesigye (2016) reported that although varieties such as Kachpot 1 are recommended for industrial processing of chips and crisps, they are not prioritized by farmers and this could potentially curtail the potato supply chain for value addition at industrial scale.

At each processing step of boiled potato, the important quality characteristics as indicated by KIls are summarized in the Table 4.

Some differences in processing/preparation of potatoes are location-specific e.g. in urban centers frying into chips or balls is a common processing/preparation method whereas in the rural areas it is boiling and steaming. A key informant also indicated that some potato varieties from the Eastern region tend to be soggy when boiled and are thus less preferred.

Also, processing or preparation method may vary depending on the age group of the final consumer e.g. mothers usually prepare mashed potato for their young children, the youth and unmarried people enjoy fast food like chips.

Table 4 Good characteristics of potato at each processing step for boiled potato product

\begin{tabular}{|c|c|c|}
\hline Preparation method & Processing step & Quality characteristics \\
\hline \multirow[t]{4}{*}{ - Boiled in water } & Peeling & $\begin{array}{ll} & \text { Uniform pale } \\
& \text { yellow/cream flesh color } \\
\text { - } & \text { Firm and stable } \\
\text { - } & \text { No pungent or off-odor } \\
\text { - } & \text { Has few buds/eyes } \\
\text { - } & \text { Big size potatoes } \\
\text { - } & \text { No dark spots inside }\end{array}$ \\
\hline & Washing & $\begin{array}{ll}\text { - } & \text { Hardness (firm in the } \\
& \text { hands) } \\
\text { - } & \text { Cream flesh color } \\
\text { - } & \text { No physical damage } \\
\text { - } & \text { No bad odor }\end{array}$ \\
\hline & Boiling & $\begin{array}{ll}\text { - } & \text { Brighter yellow color } \\
\text { - } & \text { Soft in the middle when } \\
\text { ready } \\
\text { - } & \text { Strong boiled potato } \\
\text { smell } \\
\text { - } \\
\text { Maintains cream flesh } \\
\text { color when boiling } \\
\text { - Cooks well (gets ready } \\
\text { in a reasonable time) } \\
\text { - Does not get mushy in } \\
\text { the boiling water } \\
\text { - Firm but not hard }\end{array}$ \\
\hline & Mashing (optional) & $\begin{array}{ll}- & \text { Soft } \\
- & \text { Easy to mash } \\
& \text { (Mashable) }\end{array}$ \\
\hline
\end{tabular}




\subsection{Boiled potato characteristics}

Studies on consumer preference of potato with regard to sensory characteristics in Africa are still minimal compared to other parts of the world (Anderson and Gugerty, 2015). Katundu et al. (2007) conducted acceptability studies on stored potatoes in South Africa. From their findings, preferred potatoes were characterized as having floury texture and good taste while those with bitter taste, sweet taste and soggy texture were not preferred. Sweet taste of potatoes is due to presence of reducing sugars arising from enzymatic hydrolysis of starch (Sowokinos, 2000). Bitter taste in potatoes is attributed to presence of glycoalkaloids which are associated with exposure to natural light and high temperatures especially during extended storage (Şengül et al., 2004; Katundu, 2007).

In Uganda, potato taste is one of the key attributes for farmers during varietal selection as it impacts market demand and consumption. According to CIP (2018), farmers opt for low yielding potato varieties as long as they have big tubers and good taste, especially for domestic consumption. Varieties reported to have good taste include Rwangume (NAROPOT 4), Kimuli, Bumbamagara, Kinigi and Cruza (Wachira et al., 2008). More so, potatoes that do not develop a watery texture when cooked are desirable as they do not mash when cooked (CIP, 2018). Tatwangire and Nabukeera (2017) also reported that consumers prefer varieties with good taste and do not mash during cooking. Desirable characteristics as described by key informants are shown in Table 5.

Table 5 Characteristics of good boiled potato

\begin{tabular}{|c|c|}
\hline Characteristic & Requirement/specifications \\
\hline Color & $\begin{array}{l}\text { - } \quad \text { Bright yellow color like apple banana (sukali ndizi) } \\
\text { - } \quad \text { Creamish color } \\
\text { - White color (for mashed potato) }\end{array}$ \\
\hline Texture & $\begin{array}{l}\text { - } \quad \text { Soft in the hands and mouth (easy to swallow) } \\
\text { - } \quad \text { Mealy - crumbles at slight pressure in the hands, floury } \\
\text { - } \quad \text { Firm in the hands (neither too soft nor too hard) } \\
\text { - Not mashy between fingers }\end{array}$ \\
\hline Taste & $\begin{array}{l}\text { - Good taste of boiled potato (a little bland) } \\
\text { - Not bitter }\end{array}$ \\
\hline Smell & - Strong potato smell \\
\hline
\end{tabular}

According to Montouto-Grana et al. (2011) and Seefeldt et al. (2011) texture and appearance are key sensory characteristics that influence acceptance among boiled potato consumers. Similarly, Seefeldt et al. (2011) reported yellowness, hardness, adhesiveness and moistness as important quality descriptors across three potato culinary preparations that is, boiled, mashed and oven fried. Therefore, sensory profile of one product in terms of texture, appearance and taste could be used to predict the others. 


\section{SECTION II: GENDER AND SOCIO-CULTURAL CONTEXT}

\subsection{Agronomic norms and practices of potato in different regions of Uganda}

Potato production in the East African region has doubled in the past ten years. This growth is mostly attributed to increased acreage (Sebatta et al., 2014), growing urban populations and consumer demand for convenience foods. Potato is increasingly popular because it is deemed to provide better food and income generating options when compared to other staple crops (CIP, 2008). Potato (or Irish potato as it is commonly known in Uganda) is an important strategic commodity recognized by the government as a potential driver of improved rural livelihoods (Mbowa and Mwesigye, 2016). In Uganda, potato is grown in high altitude areas such as Zombo, Isingiro, Bushenyi, Kyenjojo, Kibaale, Kabarole, Kamwenge Rakai, Mubende and Mityana districts (Okoboi, 2011). Nationally, potato yields in Uganda have remained low at an average of $7.5 \mathrm{t} / \mathrm{ha}$ compared to other countries and despite on-station yields of $25 \mathrm{t} / \mathrm{ha}$ and an achievable yield of 40-60t/ha (FAO, 2013; FAO, 2018; Okoboi et al., 2014). Majority $(93 \%)$ of farmers still rely on informal sources of seed potato, such as own saved seed, markets or neighbors; despite the fact that the quality of seed from such sources is not guaranteed (Kinyua et al., 2011). The crop is mostly cultivated by smallholder farmers with plot sizes ranging from 0.25 to 5 ha and characterized by low productivity. Low productivity is attributed to low use of improved inputs, limited access to improved seed and pests and diseases (Okwadi, 2013).

South-western Uganda, the leading potato production area (contributing $60 \%$ of national production), has the smallest per capita cropland area in Uganda (van Soesbergen et al., 2017). In this region, potatoes are usually planted as a monocrop. Farmers use Good Agriculture Practices (GAPs) such planting in straight lines, keeping gardens weed free, controlling pests and diseases and dehaulming, among others. Potatoes are usually grown in two seasons per year, except for areas with access to swamps (such as Mwizi in Kabale) or irrigation (Kapchorwa) where the crop can be grown all year round.

Potato growing households usually have a clear gender demarcated division of labor for production and marketing activities. Tatwangire and Nabukeera (2017) found that women are responsible for planting, weeding and harvesting. Men undertake seed selection, crop management (e.g. spraying and dehaulming) and marketing related activities (e.g. bagging, transporting and selling). However, Mudege et al. (2016) noted that seed selection and preservation is the domain of women.

\subsection{Access to technology}

The seed plot, negative selection, and positive selection are low-cost techniques which can, if done well, improve significantly the quality of home-saved seed potato used by smallholder farmers every season. Though these techniques could significantly improve seed quality, few farmers use them (less than 35\%). Aheisibwe et al. (2015) noted that male headed households $(\mathrm{MHH})$ were more aware of seed plot techniques $(47.6 \%$ vs $29.4 \%)$ and positive selection ( $45.8 \%$ vs $35.3 \%$ ) than female headed households ( $\mathrm{FHH})$. Overall, main reported seed-related challenges include: limited access to quality seed, distance to source (bulkiness), high cost and low awareness of quality seed.

Mugisha et al. (2017) reported that over $70 \%$ of male and female farmers respondents in a study conducted in south western Uganda had ample knowledge of recommended practices e.g. proper use of agrochemicals and dehaulming; however, few practiced them.

Due to limited fertilizer use and scarcity of labor in major potato growing areas, soil and water conservation practices are of great importance. Muzira et al. (2018) found that over $80 \%$ of 
potato fields belonging to both $\mathrm{MHHs}$ and $\mathrm{FHHs}$ in south--western Uganda had no soil conservation measures and exhibited high levels of soil degradation. However, this was more prevalent in FHHs and was linked to limited access to land which forced the households to farm on the edge of slopes thus destroying soil conservation structures. Further, FHHs were forced to rent out land to other farmers who in a bid to expand area under cultivation would inadvertently destroy conservation structures.

FHHs had more land under fallow and woodlots as compared to MHHs. This was attributed to limited resources to till land but enabled greater periods of fertility restoration; but only for households where land was not a constraining factor.

Diffused light storage (DLS) is a low-cost method to store seed potatoes and it uses indirect natural light and good ventilation to control excessive sprouting and related product loss. However, it is reported that less than $30 \%$ of farmers can afford to use them.

\subsection{Farmer access to and adoption of new potato varieties}

In the last 40 years, over 20 varieties have been introduced by NARO, CIP and the Regional Potato and Sweetpotato Improvement Program for Eastern and Central Africa (PRAPACE). Most of these varieties were resistant to late blight; a major cause of potato production losses in the country (NARO, 2017). The most popular varieties grown in the three major production regions are Rwangume (Naropot 4), Victoria and Kinigi (Namugga et al., 2015; Kyomugisha et al., 2018); and are preferred because of their disease resistance and high yields. In eastern Uganda, the variety Shangi from Kenya is becoming popular because of its suitability for boiling, reduced cooking time, early maturing, with big tubers and high yields (Sinelle, 2018).

Mudege et al. (in press) found that poverty levels are associated with the variety that farmers chose to grow. Farmers in the bottom levels of the wealth ladder tend to grow local landraces such as 'Byumba' as it doesn't require spraying. The reverse is true for wealthier farmers , as they are able to purchase and grow certified seed of released/improved varieties.

Factors hindering adoption of released varieties have been associated to low adoption of innovative crop management practices such as use of fertilizers, crop protection products, and seed selection methods, amongst others (Priegnitz et al., 2019). Farmers with limited access to land, labor and knowledge usually have the least ability to adopt innovative practices, and this translates into low adoption of new and improved varieties (ibid). Freeman and Qin (2020) also found that households with access to information have greater likelihood to use improved inputs.

Ebrahim (2019) found that amongst other factors, farmers that live near an adopter of an improved variety and have access to extension services are more likely to take up new/improved varieties. For women farmers who usually have limited access to extension services, living close to an adopter may be an important pathway for accessing new varieties.

A recent study by Thiele et al. (2020) notes that breeding programs rarely prioritize consumer preferred traits, a fact that can be associated with low uptake of improved crop varieties, including of potato. Some varieties like Cruza for example have been rejected because of poor cooking qualities (Namugga et al., 2015).

\subsection{Uses and products of potato}

In Uganda, potato is mostly consumed in the boiled form, especially in the production areas. A study conducted in eastern Uganda found that potato producing households consume $7.4 \%$ of their total production, allocate $14.8 \%$ to seed and sell $81.0 \%$ (Tatwangire and Nabukeera, 2016). Women and children are the ones who engage in preparation of boiled potatoes at home. 
Increasingly consumers prefer to eat chips and crisps, a trend driven by rapid urbanization and change in urban food eating habits (Kyomugisha et al., 2018). There is a growing presence of street food vendors in urban and peri-urban areas, and potato chips are a major component of street foods. Street food vendors prepare and process the chips using simple equipment - and these businesses are mostly operated by women, but the clients are mostly single men, or men who live without their spouses (Mackay, 2019)

Fast food chains, restaurants and hotels process potatoes into chips and sell to their customers with better value-added presentation compared to street food vendors. According to Tatwangire and Nabukeera (2017), such enterprises commanded $70 \%$ of the processed potato trade in eastern Uganda.

Potato crisps and potato sticks are other snacks prepared from potato. Magala et al. (2006) noted that the processing into potato crisps is mostly done at cottage industry level. Small scale entrepreneurs (mostly women) process between half a bag to three bags of potato on a daily basis and trade their products informally through kiosks, shops and school canteens among others. Medium-scale entrepreneurs sell to more modern outlets such supermarkets.

\subsection{Gender dimensions of the boiled potato value chain}

This section attempts to review the gender dimensions of the boiled potato value chain using the Gender Dimensions Framework (Rubin et al., 2009). The framework enables us to assess if and how women and men chain actors have access to resources such as knowledge, productive input, income and benefits thereof; beliefs and perceptions which shape gender identity and behavior; practice and participation in the chain; and laws, legal rights and institutions that govern the potato value chain.

The boiled potato value chain in the south-western and eastern regions of Uganda consists of four major actors: input suppliers, producers, traders and consumers. The roles and functions of each node of the chain is discussed in the following sections.

\subsubsection{Input supply}

Seed is one of the most important inputs in potato production, and potato farmers mostly use farm saved seed, or source it from neighbors. According to Mudege et al. (2016), women are responsible for seed selection and preservation and play a major role in ensuring maintenance of varieties from season to season. Formal seed producers are typically farmers who grow both ware and seed potato (Kyomugisha et al., 2018), and most of them are members of the Uganda National Seed Potato Producers Association (Mbowa and Mwesigye, 2016). Besides land, labor, tools and equipment, seed producers need to have access to extension services. Seed entrepreneurs also need access to market intelligence and storage space (such as DLS).

According to Sebatta et al. (2014), the seed value chain is profitable providing a return of $40 \%$, and seed producers exhibit a higher level of commercialization compared to ware producers. Only $23 \%$ of farmers add value to their seed potato, the majority $(78 \%)$ being men. From the study, seed producers were noted to use more specialized inputs and thus achieving higher yields i.e. $6.9 \mathrm{t} / \mathrm{ha}$ as compared to 5.5. t/ha reported for ware producers. Limited engagement of women in the seed business could be attributed to a lack of resources; and further highlights the issue of women being invisible actors in this activity. This also implies that women do not benefit as much as men from the lucrative seed potato business.

\subsubsection{Producers}

Potato production is traditionally a family engagement, especially at subsistence level. Women and children provide family labor for planting, weeding, dehaulming and harvesting. At commercial level, women still play this role, but as invisible actors since men dominate this 
sub-sector. Mugisha et al. (2017) found that most of commercial potato production in Western Uganda was under men management. As production progresses from subsistence to commercial, the crop becomes more of a male crop contributing $22 \%$ of annual income for men compared to $17 \%$ for women (ibid). At commercial level, male farmers hire laborers to assist with labor intensive chores such as weeding and harvesting. Pest and disease control is mostly done by men (Mudege et al., 2016). Value addition activities such sorting, grading and washing are done mostly by laborers when farmers envisage a higher price for value added potato. These activities are done under the supervision of men commercial farmers (Sebatta et al., 2014). At the marketing level, Kyomugisha et al., (2017) found that farmers need resources to transport potato from home to market, as well as for communication (telephone calls and messages), storage and packaging. From a gender perspective, in addition to limited access to these resources, women farmers may not be able to participate in marketing due to limited mobility and domestic responsibilities. Finally, it was reported that farmers who sell directly to traders incur higher transaction costs compared to those who sell to brokers, but also attain better prices and establish stronger trade networks (ibid).

\subsubsection{Traders}

Produce assembly is mostly done by rural traders and their agents, who aggregate ware potato bought directly from smallholders. This function is mostly done by men as it requires mobility and flexible working terms. According to Sebatta et al. (2014), women are less likely to participate in potato trade especially with regards to price setting and bargaining. Urban wholesale traders handle large volumes of potato procured directly from farmers or brokers and later sell their produce to rural retailers and other big buyers (Mugisha et al., 2017). This function is also done primarily by men (Kyomugisha, 2012; Mudege et al., 2016). Retail traders sell directly to consumers in small quantities and are mostly women (ibid).

\subsubsection{Processors}

\subsubsection{Boiled potato:}

Boiled potato is prepared by women with support of the female children for consumption at household level (Mudege et al., in press). In south-western Uganda, varieties with limited market demand such as Rwashaki are the ones mostly used for home consumption (Kyomugisha et al., 2018). Restaurants serve boiled/lightly fried potato for breakfast as well (ibid).

\subsubsection{Potato chips and crisps:}

Potato crisps are still mostly produced at cottage level by sole entrepreneurs, while chips are prepared and sold by street vendors in urban and peri urban centers, and also by fast food outlets. Mbowa and Mwesigye (2016) found that women are the dominant actors in the potato processing business, but also own the highest proportion of informal enterprises. For women entrepreneurs, this is primarily due to several challenges they face: limited access to business development services such as credit, networks and weak trade linkages.

Production of crisps requires more advanced equipment (e.g. for packaging and branding) and skills as compared to chips - which forms an entry barrier for aspiring entrepreneurs. Inadequate storage of tubers is a limiting factor that curtails profits from potato processing. This is further exacerbated by inconsistent supplies, especially in months of low production.

According to Kyomugisha et al. (2018), processors prefer Rwangume, Victoria and Kinigi varieties for making chips. Processor prefer varieties with high dry matter, few eyes and red skin (Mbowa and Mwesigye, 2016). However, processors face difficulties in accessing the desired varieties due to a host of reasons but mostly related to inadequate seed supply, low yields, long maturity time and susceptibility to pests and diseases (ibid). Another challenge which processors in urban markets face is the mixing of varieties at source. This implies that 
processors have to sort the potatoes in the market before purchase, for avoiding ending up with tubers that are not fit for processing (Magala et al., 2006).

\subsection{Trade-offs between different uses of potato and policy issues}

For women, the primary purpose for growing potato is food security given their responsibility of ensuring food availability in the household. As such, their plots and related cultivation practices are geared towards subsistence farming. Men, on the other hand, are more likely to grow for commercial purposes - as reflected by the level and quality of inputs they use. However, while commercial farmers endeavor to purchase seed, many still depend on farm saved seed; and hence select quality large tubers for this purpose (Mbowa and Mwesigye, 2016).

In times of food scarcity, there are conflicting priorities for the household: the desire to put food on the table; and the foresight to ensure seed availability for the next planting season. This may create tensions within the households and at times lead to domestic violence; with women bearing the brunt of this trade off (Mudege et al., 2016).

\section{Potato products primarily under women's control:}

Women are responsible for seed acquisition and preservation for subsistence and in some cases, for commercial purposes. They are also in charge of food availability in the home and thus determine when and how to prepare and consume boiled potato. Preparation and sale of chips as a street food is also done primarily by women (Tatwangire and Nabukeera 2017).

\section{Potato products primarily under men's control:}

Men dominate multiplication and sale of seed through formal seed channels. They also control commercial sales of ware potato (Mudege et al., 2016). However, as noted above, women play an important role in seed selection and conservation but their role is not recognized. This might be linked to the fact that potato is largely considered a man's crop, especially when grown for income (Walukano et al., 2016). Efforts to achieve increased productivity are supported by policy instruments such as the National Seed Policy and the National Fertilizer Policy to address the yield gap; and the National Extension Policy to address the knowledge gap. Given the proven productivity increment that quality seed ensures, high yielding varieties are likely to be increasingly adopted (ibid). However, women farmers are likely to be barred from participating in sustainable intensification programs due to limited access to natural and productive resources. This implies that women may not be able to adopt new varieties to the same extent as men, more so if they do not meet their preferred characteristics or traits.

According to Ortiz et al. (2016), farmer institutions and private seed companies are pivotal players in the quest for availing quality seed. However, most of the farmer institutions such as Uganda National Seed Potato Producers Association (UNSPPA) and Wanale Seed and Ware Potato Producers Association (WASWAPPA) are led by and dominated by men; with the few women members holding 'token' positions (Mudege et al.; 2016). This disparity further alienates women's participation in quality seed production and, ultimately, the whole performance of the sector.

Similarly, potato marketing associations such as Mbale Potato Dealers Association (MPODA) are dominated by men wholesalers with limited participation of women - who are mostly retailers with limited bargaining power and ability to voice the needs of the last mile in the chain, the consumers (ibid). 


\section{SECTION III: DEMAND ASSESSMENT}

\subsection{Market demand for potatoes in Uganda}

The market demand for potato in Uganda is expanding and this is attributed to the rapid urban population growth and changing food eating habits of urban dwellers. To a great extent, potato is demanded by the urban population in various forms including chips, crisps and French fries (J.G. Wang'ombe, 2008; Jansky et al., 2009). This brings small scale processors into the value chain. The most common marketing channel is characterized by farmers selling on cash basis to wholesalers who in turn transport the potatoes to urban centers (L. Aliguma et al., 2007; Tatwangirwe and Nabukeera, 2017)]. Marketing channels in urban centres include wholesale markets and small shops in Kampala (Kaganzi et al., 2008). Traders also sell potatoes to higher value outlets such as supermarkets, restaurants and fast-food chains (BonabanaWabbi et al., 2013).

\subsection{Value chain actors and demand trends}

Growing urbanization and demand from urban consumers have provided emerging market potentials for potato and potato products (Bonabana-Wabbi et al., 2013). Although potato production is largely localized in few areas of Uganda, its supply chain commonly ends in almost all the urban markets and restaurants in the country, hence bringing many market chain actors into play. The level of potato marketing and domestic demand of ware potato products is on the increase. Key players along the ware potato value chains include farmers, agents (or brokers), local traders, urban wholesalers, urban retailers, processors, and consumers. It is noted that most wholesalers sell directly to markets and hotels in big towns such as Kampala. Products from the processing of potato tubers include boiled potato, chips, and crisps (Tatwangire and Nabukeera, 2017). Some industries, such as those owned by Uganda Industries Research Institute (UIRI), process potatoes into quality crisps (Mbowa and Mwesigye, 2016). Various institutions such as schools, hotels, and hospitals also procure and consume ware potatoes in large quantities. (Tatwangire and Nabukeera, 2017). Travelling traders who either own trucks or hire them for buying potatoes from farmers or village traders and then transport and sell to wholesalers and urban retailers in other district markets are key players in the value chain. These traders supply most of the potatoes to wholesalers and retailers through brokers (Ferris et al., 2001).

From the key informant interviews, value chain actors associated with potato include the following.

- Bulk buyers/ transporters/ dealers who buy directly from farmers; transport and sell in major markets to wholesalers and retailers.

- Brokers who buy from farmers on behalf of the wholesalers who in turn transport to urban areas and sell to other wholesalers, retailers within major markets, retailers at other locations, hotels, restaurants and institutions.

- Small scale retailers who buy potatoes ranging from half to many sacs and sell the tubers to individual buyers, hoteliers, restaurants, kiosks and roadside dealers.

- Individual buyers who buy for home consumption.

- Hotels and restaurants who buy fresh potatoes and sell it boiled, fried or fried chips.

- Kiosk and fast food restaurant dealers who buy fresh potato from retailers and sell in form of fried chips.

- Roadside dealers/ small scale processors who also buy potato in fresh form from retailers and sell it in form of fried chips.

- Farmers and farmer organizations.

- People living in and around production areas. 


\subsubsection{Size of the different value chains and trends}

Within the major production areas, wholesale buyers provide the biggest market outlet for fresh potatoes, as they buy the fresh product in large quantities from farmers either directly or through agents (brokers); and transport it to distant urban and peri-urban markets. In urban areas, over $50 \%$ of potatoes are likely to be consumed as chips (Ferris et al., 2001). Hotels, restaurants and take-aways (fast-food outlets) are the main business enterprises that process potatoes into chips. These processors provide a big market for the traders of fresh potatoes. On the contrary, processors within the major production areas provide the smallest market outlet for potatoes. These process potatoes into chips and crisps on a very small scale. Chips are mainly sold to fast food customers, while crisps are sold to supermarkets. In low production areas, end consumers are the number one buyers of potatoes because farmers are more likely to sell small quantities to neighbors (and in local towns) for final consumption than to other market segments (Mbowa and Mwesigye, 2016).

From Table 6, information obtained from the key informants shows wholesalers, processors, and retailers in urban and peri-urban markets as the biggest value chain actors, followed by retailers within the major urban markets. Individual consumers, hotels, restaurants and institutions were noted to be at the lower end of the value chain.

Table 6 Size of value chains in urban and peri-urban markets according to the KIIs

\begin{tabular}{|l|c|}
\hline Demand segment & Size \\
\hline Wholesalers & $40 \%$ \\
\hline Traders/ retailers within major urban markets & $10-20 \%$ \\
\hline Retailers in peri-urban markets & $40-50 \%$ \\
\hline Household / individual consumers & $5 \%$ \\
\hline Processors/ roadside kiosk dealers & $40 \%$ \\
\hline Hotels and restaurants & $5 \%$ \\
\hline Institutions & $5 \%$ \\
\hline
\end{tabular}

\subsubsection{Geographical and demographic characteristics of the value chain actors}

Urban wholesalers mainly come from towns near the production areas and Kampala districts. Mbale town is the current potato hub in eastern Uganda where traders from different places meet to re-weigh, sort, and package potatoes before shipping them to different destination markets such as Kampala city and Lira, and including export markets in South Sudan and other neighboring countries (Tatwangirwe and Nabukeera, 2017).

Information obtained from the KIls reveals that wholesale buyers and transporters usually travel from urban areas to production areas to purchase fresh potato. These are mainly adult men and business people because potato is a high value crop (communication by female research officer, NARO). Men are also physically stronger and resilient, and have the ability to stay away from home for a long time while handling the process of purchasing, loading and transport of fresh potatoes from production areas to market places while women have to stay home and deal with housekeeping duties (communication by male researcher, NARO). Brokers who are usually men and a few women in production areas connect wholesale buyers 
to farmers. The potato value chain comprises of people across regions, ethnic groups and religions.

Retailers who sell the fresh product in smaller quantities are mostly women. According to a male key informant, women have the patience to sell a few sacs of potato over a number of days to obtain a little profit while men have less patience; and under pressure to earn large profits over a short period of time to take care of their households. A trader at Wekembe market recounted that female retailers are 30 years and above, with mixed marital status though most of them are married with families under their care. On the other hand, individual buyers include both men and women, whether single or married, youths and children who buy the fresh product for home consumption. These mostly consume the product in boiled and fried forms.

Key informants revealed that hotels and restaurants buy fresh potatoes and sell it boiled in addition to other foods, fried or fried chips. Hotel chefs and restaurant owners are majorly male and a few women. Small scale processors buy fresh potato from retailers and sell in form of fried chips. These include men and women across ages and ethnic groups. Roadside dealers/ small scale processors are usually male and female youths between 20 and 30 years old, mostly singles.

Furthermore, people living in and around production areas mainly consume potato in boiled form as a staple food. However, according to a male researcher at NARO, demand for potatoes among people in production areas is low. He attributed this to the fact that potatoes are expensive, yet people in those areas have low incomes. He added that although potatoes may appear cheaper in production areas, they are not affordable. However, other respondents indicated that at times farmers in production areas, get tired of eating potatoes to an extent that they may receive a kilogram of sugar in exchange for the potatoes.

Most of the demand segments stated are found in urban and peri-urban areas where the population is high and demand is geared mostly towards fast foods, and easy to cook foods including potatoes.

\subsubsection{Profitability}

Potatoes flow through a multi-staged marketing channel i.e. through a few different value chain actors before reaching the final consumer. This implies that profits are shared by many players along the chain. Potato prices are mainly set by traders depending on tuber availability and distance to target markets. Profits earned by traders are higher when no brokers are involved in the value chain than when they are present (Tatwangirwe and Nabukeera, 2017). For the producers, potato enterprise is a profitable one, returning more than the original investment in purchased inputs and labor (Bonabana-Wabbi et al., 2013).

Travelling traders with high quality fresh potatoes typically increase their prices relative to those prevailing in the market. Conversely, they reduce the price when sales are slower than they had anticipated, and quality starts to degenerate. They then sell at clearance prices to avoid additional costs such as accommodation costs, overnight parking fees, product loss and transport surcharge from truck owners. Travelling traders sometimes also sell at a loss especially when there is excess potato supply on the market coupled with gluts in other alternative foodstuffs like cooking bananas, sweetpotato and cassava (Ferris et al., 2001).

\subsection{Preferred characteristics of potato by the different value chain actors}

The different potato varieties available in markets include Rwashaki, Kinigi, Sutama, Victoria, and Kachpot 1. The first four provide the highest marketing margins in Kabale and Kisoro districts (Bonabana- Wabbi et al., 2013). It is noteworthy that most traders and consumers in 
urban areas refer to potato varieties as Kabale, Kisoro, Fort (Fort Portal), and Mbale relating potato variety to production area (communication from Wekembe market traders).

The high demand for Kachpot 1 is explained by its high dry matter content and smooth red skin, which is suitable for processing. Low dry matter content and "deep eyes" that lead to wastage when peeling are undesirable characteristics of Victoria variety, while "blemish rings" coloring characteristic of Kinigi variety also lower its quality (Mbowa and Mwesigye, 2016). Uganda's Rutuku which has the same characteristics as Victoria is highly sought after by traders, for its chip making quality. Its characteristics are large tuber size, red/light red skin color and yellow/cream flesh.

As summarized in Table 7, information obtained from the Klls presents little variation in the preferred characteristics among the different value chain actors. Most people prefer yellow fleshed potatoes that are hard when raw and firm when cooked. However, the key informants noted that variation in skin color of raw potato may not necessarily indicate potato quality. Potato processors prefer hard potatoes due to their ability to retain the shape after frying i.e. they do not become soggy or crushed.

Preference of retailers, individual consumers, and processors (such as roadside dealers, and fast food restaurants) is geared towards potato variety, maturity and big size; potato processability characteristics such as low oil absorption, and final product characteristics such as taste and shape retention after cooking. Processors prefer big sized potatoes because they give more chips, increasing profitability. Wholesalers usually focus on low price of potatoes, availability of large quantities, potato variety and potato maturity.

Table 7 Preferred characteristics for potato per value chain actor according to the KIIs

\begin{tabular}{|l|l|}
\hline Demand segment & Characteristics \\
\hline Producers & $\begin{array}{l}\text { High yield } \\
\text { Resilience }\end{array}$ \\
\hline Bulk buyers/ transporters/ dealers & Maturity \\
\hline Wholesalers & Maturity \\
\hline Traders/ retailers with in major urban markets & $\begin{array}{l}\text { Firm tuber } \\
\text { Medium/ big tuber size }\end{array}$ \\
\hline Retailers at other locations & $\begin{array}{l}\text { Firm tuber } \\
\text { Medium/ big tuber size }\end{array}$ \\
\hline Household / individual consumers & $\begin{array}{l}\text { Firm tuber } \\
\text { Low oil absorption } \\
\text { Yellow flesh } \\
\text { Shape retention after cooking }\end{array}$ \\
\hline Processors/ roadside / kiosk dealers & $\begin{array}{l}\text { Low oil absorption } \\
\text { Firm potato when cooked } \\
\text { Red skin color } \\
\text { Good taste of cooked potato } \\
\text { Medium/ big tuber size } \\
\text { Maturity } \\
\text { Yellow flesh } \\
\text { High dry matter content } \\
\text { Smooth skin } \\
\text { Shape retention after cooking }\end{array}$ \\
\hline Hotels and restaurants & Firm potato \\
\hline
\end{tabular}


According to the traders at Wekembe market, varieties preferred by the market were Kisoro, and Kabale. These are hard when raw, firm when cooked, take up little oil, do not dry quickly and have a good yellow appearance. Kisoro has medium and large tubers, white skin and cream flesh, while Kabale is characterized by large tubers, purple/ white skin and white flesh.

An overview table summarizing the value chain actors and preferred characteristics for potato has been included in the appendix section.

\subsection{Transportation, storage and sale of the potato product}

On farm, potato is packed in gunny bags and stored in specialized structures or in a farmer's house. Transportation to the market is done either using bicycles, head loads or motor vehicles (trucks, pickups) (Mbowa and Mwesigye, 2016). Bulk buyers, wholesalers and transporters use trucks i.e. Fusos, Kantas and lorries to transport large quantities of fresh potatoes from production areas to urban and peri-urban areas where they sell the product to other wholesalers, retailers and institutions. These trucks carry a minimum of 100 bags of fresh potato each bag weighing $120 \mathrm{~kg}$. Within the production areas, peri-urban and urban areas; bicycles, head carriage, pickups, taxis and personal vehicles are used to transport the fresh product along short distances from both major and minor markets (communication by Wekembe market traders). In urban and peri-urban markets, storage facilities for the fresh product include bulk stores and market sheds with regards to wholesalers. These keep the potatoes in bags. Retailers store the product in mini stores, shops and verandas (communication by female research officer, NARO). Additionally, traders report that although some retailers store the fresh product in open spaces in the market, these expose the fresh product to water (from rain) and humid conditions that induce rotting, hence spoilage and low profitability of the product. For these reason, retailers and wholesalers in the market either store the fresh product in bags under sheds or cover the potatoes with tarpaulins (communication by Wekembe market traders).

High transport costs, which are attributed to mechanical breakdowns and bad roads are one of the major challenges faced by potato traders, hence greatly contribute to the high market prices of the product (Mbowa and Mwesigye, 2016). Besides, lack of organized storage translates into high postharvest losses among farmers, traders, and processors (Mbowa and Mwesigye, 2015). These challenges in addition to poor communication facilities, high costs of electricity, lack of pre-cooling and pack houses, limited access to cold and dry storage facilities make it difficult for value chain actors to successfully market their produce (MAAIF, 2010). Improving transport, storage, and market infrastructure can therefore reduce marketing costs so that households in more remote areas can benefit more from commercialization.

With regard to sales, it is noteworthy that the product is sold fresh by both men and women of various ethnicities and religious backgrounds at various stages of the potato value chain. However, wholesalers (buying directly from producers) are mostly men who, according to the key informants, are physically strong and resilient. At the market, wholesalers sell the product in bags, large scale retailers sell the fresh product in bags, basins, heaps and tins while smallscale retailers, mostly women, sell in small polythene bags and tins. Processors who sell the potatoes in form of chips include majorly male and female youths. Fried potato chips are sold in paper bags, polythene bags and containers, while boiled potato in hotels and restaurants is usually served in addition to other dishes (communication by Wekembe market trader). 


\section{CONCLUSIONS}

While efforts have been made to introduce new improved potato varieties in Uganda, adoption rates are low; especially by women farmers. Nonetheless, the most preferred varieties are released varieties such as Rwangume (Naropot 4), Victoria and Kinigi. There are gender specific roles in the seed and ware potato chains, with seed production being dominated by men, though women play an important role in seed management. In the ware potato chain, the wholesale function is dominated by men while women are more prevalent in retail and processing boiled potato. Preferences for raw, processed and boiled potato were similar amongst various end-users in the value chain. Producers, traders and consumers all preferred red skin, yellow flesh, smooth skin and big tubers among raw potato characteristics. Processor preferences were similar, however, in addition, shallow eye depth, high dry matter and low sugar content were a requirement. A good boiled potato was defined by consumers as being mealy, having a bright yellow color, good potato taste and smell. The information obtained in this study with regards to food science requires translation into objective physicochemical measurements and sensory evaluation that can be used by breeders to improve the potato varieties to meet specific end-user requirements. Additionally, a vast amount of literature has been generated on potato production, potato value chain, and performance of potato markets in Uganda. However, limited literature is available regarding potato demand size, trends and profitability in Uganda's urban and peri-urban areas which calls for additional research in this area. 


\section{REFERENCES}

Abong, G. O., Okoth, M. W., Karuri, E. G., Kabira, J. N. Mathooko, F. M., 2009. Evaluation of selected Kenyan potato cultivars for processing into French fries. Journal of Animal and Plant Science. 2, 141-147.

Aheisibwe, A.R., Barekye, A., Namugga, P. and Byarugaba, A.A., 2015. Challenges and opportunities for quality seed potato availability and production in Uganda. Uganda Journal of Agricultural Sciences, 16(2), pp.149-159.

Aliguma, L., Magala, D. and Lwasa, S. 2007. Connecting smallscale producers to markets: The case of the Nyabyumba United Farmers Group in Kabale district, Uganda. Uganda Agricultural Economics Association (UAEA).

Anderson, L. and Gugerty, M.K., 2015. Root, Tuber, and Banana Textural Traits a Review of the available Food Science and Consumer Preferences Literature. Evans School of Public Affairs, University of Washington. EPAR Brief, (295).

Bonabana-Wabbi J., Ayo S., Mugonola B., Taylor D.B., Kirinya J. and Tenywa. 2013. The performance of potato markets in South Western Uganda, Journal of Development and Agricultural Economics, Vol. 5(6), pp. 225-235.

CIP, 2018. Literature based mapping and analysis of the Ugandan potato value chain. Working Paper

Ebrahim, M., 2019. Adoption of improved potato varieties and its impact on household nutrition: Evidence from Emba Alaje Woreda, northern Ethiopia (Doctoral dissertation, Bahir Dar University).

Food Agriculture Organization of the United Nations (2018). FAO Stat. Retrieved from: http://faostat3.fao.org/browse/Q/QC/E

FAO 2015. Strengthening linkages between small actors and buyers in the Roots and Tubers sector in Africa. Project Inception Workshop Report.

FAOSTAT, 2019. http://www.fao.org/faostat/en/\#data/CC.

Ferris R.S.B., Okoboi G., Crissman C., Ewell P. and Lemaga B., 2001, Uganda's Irish Potato Sector, Prepared for Uganda's Conference on Competitiveness of Selected Strategic Exports by IITA-Foodnet, CIP, PRAPACE, CGIAR and ASARECA on behalf of the European Commission.

Freeman, K. and Qin, H., 2020. The Role of Information and Interaction Processes in the Adoption of Agriculture Inputs in Uganda. Agronomy, 10(2), p.202.

IFDC, 2017. Assessment of Uganda's Potato Market System. REACH-Uganda Project.

J.G. Wang'ombe, 2008. The potato value chain in Kenya and Uganda. Maastricht School of management, DBA assignment.

Katundu, M.G., Hendriks, S.L., Bower, J.P. and Siwela, M., 2007. Effects of traditional storage practices of small-scale organic farmers on potato quality. Journal of the Science of Food and Agriculture, 87(10), pp.1820-1825.

Katundu, M., Hendriks, S., Bower, J. and Siwela, M., 2010. Can sequential harvesting help small holder organic farmers meet consumer expectations for organic potatoes? Food quality and preference, 21(4), pp.379-384.

Kyanjo, L.J., Mugisha, J. and Bagamba, F., 2016. Determinants of adoption of potato production in the low land areas of Uganda. In Fifth African Higher Education Week and RUFORUM Biennial Conference 2016," Linking agricultural universities with civil society, the 
private sector, governments and other stakeholders in support of agricultural development in Africa", Cape Town, South Africa, 17-21 October 2016 (pp. 595-600). RUFORUM.

Kyomugisha, H., Mugisha, J., Katungi, E., Kasharu, A., Sebatta, C., Books, R.U.F.O.R.U.M., OER, R., SCARDA, R. and Tenders, R.U.F.O.R.U.M., 2013. Economic evaluation of the potato market chain in Uganda (Doctoral dissertation, Makerere University).

Kyomugisha, H., Mugisha, J. and Sebatta, C., 2017. Potential determinants of profits and market efficiency of potato market chains in Uganda. Journal of Agribusiness in Developing and Emerging Economies.

Kyomugisha, H., Sebatta, C. and Mugisha, J., 2018. Potato market access, marketing efficiency and on-farm value addition in Uganda. Scientific African, 1, p.e00013.

Mackay, H., 2019. Food sources and access strategies in Ugandan secondary cities: an intersectional analysis. Environment and urbanization, 31(2), pp.375-396.

Mbowa S. and Mwesigye F., 2016. Investment Opportunities and Challenges in the Irish Potato Value Chain in Uganda. PASIC \& EPRC.

Mugisha, J., Mwadime, R., Sebatta, C., Gensi, R., \& Obaa, B. (2017). Factors enhancing household nutrition outcomes in potato value chain in South-Western Uganda. Journal of Sustainable Development; 10, No.3. 2017

Muhumuza, E., Edema R, Namugga, P. and Alex Barekye, A., 2020. Evaluation of Potato Genotypes for Desirable Processing Tuber Attributes in Uganda. American Journal of Agricultural Science. 7 (1),pp. 17-24.

Muzira, R., Tenywa, J.S. and Basamba, T. (2018) Linking Soil Conservation in Potato Production Systems in the Highlands of South Western Uganda to Gender and Farmer-Market Types. Open Access Library Journal, 5: e4422. https://doi.org/10.4236/oalib.1104422

Namugga, P., Melis, R., Sibiya, J. and Barekye, A., 2017. Participatory assessment of potato farming systems, production constraints and cultivar preferences in Uganda. Aust J Crop Sci, $11, \mathrm{pp} .932-940$.

NARO, 2017. National variety list for Irish Potato

National Planning Authority, National Development Plan II and Agricultural Sector Strategic Plan for 2015/16-2019/20, National Planning Authority, Government of Uganda, Kampala, 2015.

Nuwamanya, E., Baguma, Y., Wembabazi, E. and Rubaihayo, P., 2011. A comparative study of the physicochemical properties of starches from root, tuber and cereal crops. African Journal of Biotechnology, 10(56), pp.12018-12030.

Okoboi, G., Kashaija, I., Kakuhenzire, R., Lemaga, B., and Tibanyendera, D. (2014). "Rapid assessment of potato productivity in Kigezi and Elgon highlands in Uganda," in Challenges and Opportunities for Agricultural Intensification of the Humid Highland Systems of SubSaharan Africa, Eds B. Vanlauwe, P. Van Asten, and G Blomme (Switzerland: Springer International Publishing), 29-37. doi: 10.1007/978-3-319-07662-1_3

Ortiz, O., Orrego, R., Pradel, W., Gildemacher, P., Castillo, R., Otiniano, R., Gabriel, J., Vallejo, J., Torres, O., Woldegiorgis, G. and Damene, B., 2013. Insights into potato innovation systems in Bolivia, Ethiopia, Peru and Uganda. Agricultural Systems, 114, pp.73-83.

Okwadi J., Overview of the Potato Sector in Uganda, Stepping Stones Consulting Associates Ltd, October 2013.

PASIC, 2015. Community and market survey of potato VC actors. 
Pedreschi, F., 2012. Frying of Potatoes: Physical, Chemical, and Microstructural Changes. Drying Technology. 30, 707-725. doi: 10.1080/07373937.2012.663845.

Priegnitz, U., Lommen, W.J., Onakuse, S. and Struik, P.C., 2019. A farm typology for adoption of innovations in potato production in SouthWestern Uganda. Frontiers in Sustainable Food Systems, 3, p.68.

Rakotosamimanana, V. R. and De Kock, H. L., 2020. Sensory studies with low-income, foodinsecure consumers. Current Opinion in Food Science.

Rubin, D., 2011. Gender Dimensions Framework Application. https://vtechworks.lib.vt.edu/handle/10919/69076

Sebatta, C., Mugisha, J., Katungi, E., Kasharu, A., Kyomugisha, H., Books, R.U.F.O.R.U.M., OER, R., SCARDA, R. and Tenders, R.U.F.O.R.U.M., 2012, September. Determinants of smallholder farmers' participation in the potato market in Kabale and Mbale. In Third Ruforum Biennal meeting (pp. 24-28).

Sebatta C., Mugisha J., Katungi E., Kashaaru A. and Kyomugisha H., 2014, Smallholder Farmers' Decision and Level of Participation in the Potato Market in Uganda, Modern Economy, 5, 895-906.

Sebatta, C., Mugisha, J., Katungi, E., Kasharu, A. K., \& Kyomugisha, H. (2014). Adding Value at the Farm: The Case of Smallholder Potato Farmers in the Highlands of Uganda. Asian Journal of Agricultural Extension, Economics \& Sociology, 4(3), 210-223. https://doi.org/10.9734/AJAEES/2015/13844

Seefeldt, H.F., Tønning, E. and Thybo, A.K., 2011. Exploratory sensory profiling of three culinary preparations of potatoes (Solanum tuberosum L.). Journal of the Science of Food and Agriculture, 91(1), pp.104-112.

Şengül, M., Keleş, F. and Keleş, M.S., 2004. The effect of storage conditions (temperature, light, time) and variety on the glycoalkaloid content of potato tubers and sprouts. Food Control, 15(4), pp.281-286.

Sikuku, M.D. and Ogemah, V., 2005. Improving Small Holder Marketing of Potatoes and Ground nuts in Eastern Uganda. Field technical report http://www.fao.org/docs/eims/upload/agrotech/1990/R8435 FTR anx5.pdf

Sinelle, S. (2018). Potato Variety Adoption and Dis-Adoption in Kenya. p. 63. Lima: Syngenta Foundation, International Potato Center.

Sowokinos, J.R., Shock, C.C., Stieber, T.D. and Eldredge, E.P., 2000. Compositional and enzymatic changes associated with the sugar-end defect in Russet Burbank potatoes. American Journal of Potato Research, 77(1), pp.47-56.

Tatwangire, A. and Nabukeera, C., 2017. Technical Report RTB Endure: Market and value chain analysis of ware potato from Eastern Uganda with a focus on postharvest management practices and losses.

Tesfaye A., Lemaga B., Mwakasendo J.A., Nzohabonayoz Z., Mutware J., Wanda K.Y., Kinyae P.M., Ortiz O., Crissman C. and Thiele G., 2010. Markets for fresh and frozen potato chips in the ASARECA region and the potential for regional trade: Ethiopia, Tanzania, Rwanda, Kenya, Burundi and Uganda, Working Paper, CIP.

Tindimubona, S., Barekye, A., Rwomushana, I., Kanzikwera, R., Isabirye, B. and Biryomumaisho, B., 2014. Access to improved seed potato and seed entrepreneurship in South-Western Uganda. Seed Systems, Science and Policy in East and Central Africa, p.58. 
UBOS \& MAAIF 2011. Uganda Census of Agriculture (UCA) 2008/09 at a Glance. Uganda Bureau of Statistics (UBOS) and Ministry of Agriculture Animal, Industry, and Fisheries (MAAIF).

Van Soesbergen, A., van Soesbergen, A., Arnell, A.P., Sassen, M. and Stuch, B. (2017) Exploring Future Agricultural Development and Biodiversity in Uganda, Rwanda and Burundi: A Spatially Explicit Scenario-Based Assessment. Regional Environmental Change, 17, 14091420.

https://doi.org/10.1007/s10113-016-0983-6

Wachira, K., Gildemacher, P., Demo, P., Wagoire, W., Kinyae, P., Andrade, J., Fuglie, K. and Thiele, G., 2008. Farmer practices and adoption of improved potato varieties in Kenya and Uganda. Social Sciences Working paper, Lima

Walukano, W., Pali, P.N., Wairegi, L., Nanfumba, D., Arinaitwe, A., Basalirwa, D., Asiimwe, R. and van Asten, P.J., 2016. Yield gap analyses to inform policy on Sustainable Crop Intensification pathways in Uganda. 


\section{APPENDICES}

\subsection{APPENDIX A: OVERVIEW TABLE OF THE POTATO VALUE CHAIN AND PREFERRED CHARACTERISTICS}

\begin{tabular}{|c|c|c|c|c|c|c|}
\hline $\begin{array}{l}\text { Value chain } \\
\text { actors }\end{array}$ & $\begin{array}{l}\text { Characteristics } \\
\text { preferred }\end{array}$ & $\begin{array}{l}\text { Size of demand } \\
\text { segment }\end{array}$ & $\begin{array}{l}\text { Profitability /value } \\
\text { of the product by } \\
\text { value chain actor }\end{array}$ & $\begin{array}{l}\text { Geographic } \\
\text { location }\end{array}$ & $\begin{array}{l}\text { Socio-economic } \\
\text { characteristics of } \\
\text { value chain actor } \\
\text { (income, gender, } \\
\text { age, etc.) }\end{array}$ & $\begin{array}{l}\text { Main sources of } \\
\text { information }\end{array}$ \\
\hline Producers & $\begin{array}{l}\text { High yield } \\
\text { Resilience }\end{array}$ & & $\begin{array}{l}\text { Highly profitable } \\
\text { across seasons }\end{array}$ & $\begin{array}{l}\text { Production areas } \\
\text { (Kabale, Kisoro, } \\
\text { Kapchorwa, Mbale, } \\
\text { Masaka) } \\
\text { Urban areas }\end{array}$ & $\begin{array}{l}\text { Majorly men } \\
\text { because it's a high } \\
\text { value crop } \\
\text { Business people } \\
\text { Adults } \\
\text { All races }\end{array}$ & $\begin{array}{l}\text { Visits to major } \\
\text { market outlets such } \\
\text { as Kalerwe, Owino, } \\
\text { Nakasero }\end{array}$ \\
\hline $\begin{array}{l}\text { Bulk buyers/ } \\
\text { transporters/ } \\
\text { dealers }\end{array}$ & Maturity & & $\begin{array}{l}\text { Highly profitable } \\
\text { across seasons }\end{array}$ & $\begin{array}{l}\text { Major urban } \\
\text { markets such as } \\
\text { Nakasero, Kalerwe }\end{array}$ & $\begin{array}{l}\text { Men of High- } \\
\text { income status } \\
\text { All races }\end{array}$ & $\begin{array}{l}\text { Visits to major } \\
\text { market outlets such } \\
\text { as Kalerwe, Owino, } \\
\text { Nakasero }\end{array}$ \\
\hline Wholesalers & Maturity & $40 \%$ & $\begin{array}{l}\text { Highly profitable } \\
\text { during peak } \\
\text { season, } \\
\text { Less profitable } \\
\text { during off peak }\end{array}$ & $\begin{array}{l}\text { Major urban } \\
\text { markets }\end{array}$ & & $\begin{array}{l}\text { Kachwekano } \\
\text { ZARDI (KaZARDI) } \\
\text { - NARO }\end{array}$ \\
\hline $\begin{array}{l}\text { Traders/ retailers } \\
\text { with in major } \\
\text { urban markets }\end{array}$ & $\begin{array}{l}\text { Firm roots } \\
\text { Medium/ big root } \\
\text { size }\end{array}$ & $10-20 \%$ & $\begin{array}{l}\text { Profitable during } \\
\text { peak seasons }\end{array}$ & & & \\
\hline
\end{tabular}




\begin{tabular}{|c|c|c|c|c|c|c|}
\hline $\begin{array}{l}\text { Retailers at other } \\
\text { locations }\end{array}$ & $\begin{array}{l}\text { Firm root } \\
\text { Medium/ big root } \\
\text { size }\end{array}$ & $40-50 \%$ & & $\begin{array}{l}\text { Urban areas and } \\
\text { peri urban areas } \\
\text { Production areas } \\
\text { where potato is a } \\
\text { staple food }\end{array}$ & & UBOS report \\
\hline $\begin{array}{l}\text { Household / } \\
\text { individual } \\
\text { consumers }\end{array}$ & $\begin{array}{l}\text { Firm root } \\
\text { Low oil absorption } \\
\text { Yellow flesh }\end{array}$ & $5 \%$ & $\begin{array}{l}\text { Highly profitable } \\
\text { during peak } \\
\text { season, but less } \\
\text { profitable during off } \\
\text { peak season }\end{array}$ & $\begin{array}{l}\text { Urban and peri- } \\
\text { urban areas }\end{array}$ & $\begin{array}{l}\text { Youths across } \\
\text { gender } \\
\text { Middle aged men } \\
\text { and women } \\
\text { All races }\end{array}$ & \\
\hline $\begin{array}{l}\text { Processors/ } \\
\text { roadside kiosk } \\
\text { dealers }\end{array}$ & $\begin{array}{l}\text { Low oil absorption } \\
\text { Firm potato when } \\
\text { cooked } \\
\text { Red skin color } \\
\text { Good taste of } \\
\text { cooked potato } \\
\text { Medium/ big root } \\
\text { size } \\
\text { Maturity } \\
\text { Yellow flesh } \\
\text { High dry matter } \\
\text { content } \\
\text { Smooth skin }\end{array}$ & $40 \%$ & & Urban areas & $\begin{array}{l}\text { Majorly men } \\
\text { All races }\end{array}$ & \\
\hline $\begin{array}{l}\text { Hotels and } \\
\text { restaurants }\end{array}$ & Firm potato & $5 \%$ & & Peri - urban areas & & \\
\hline Institutions & & & & & & \\
\hline
\end{tabular}


8.2 APPENDIX B: MAJOR POTATO GROWING DISTRICTS IN UGANDA

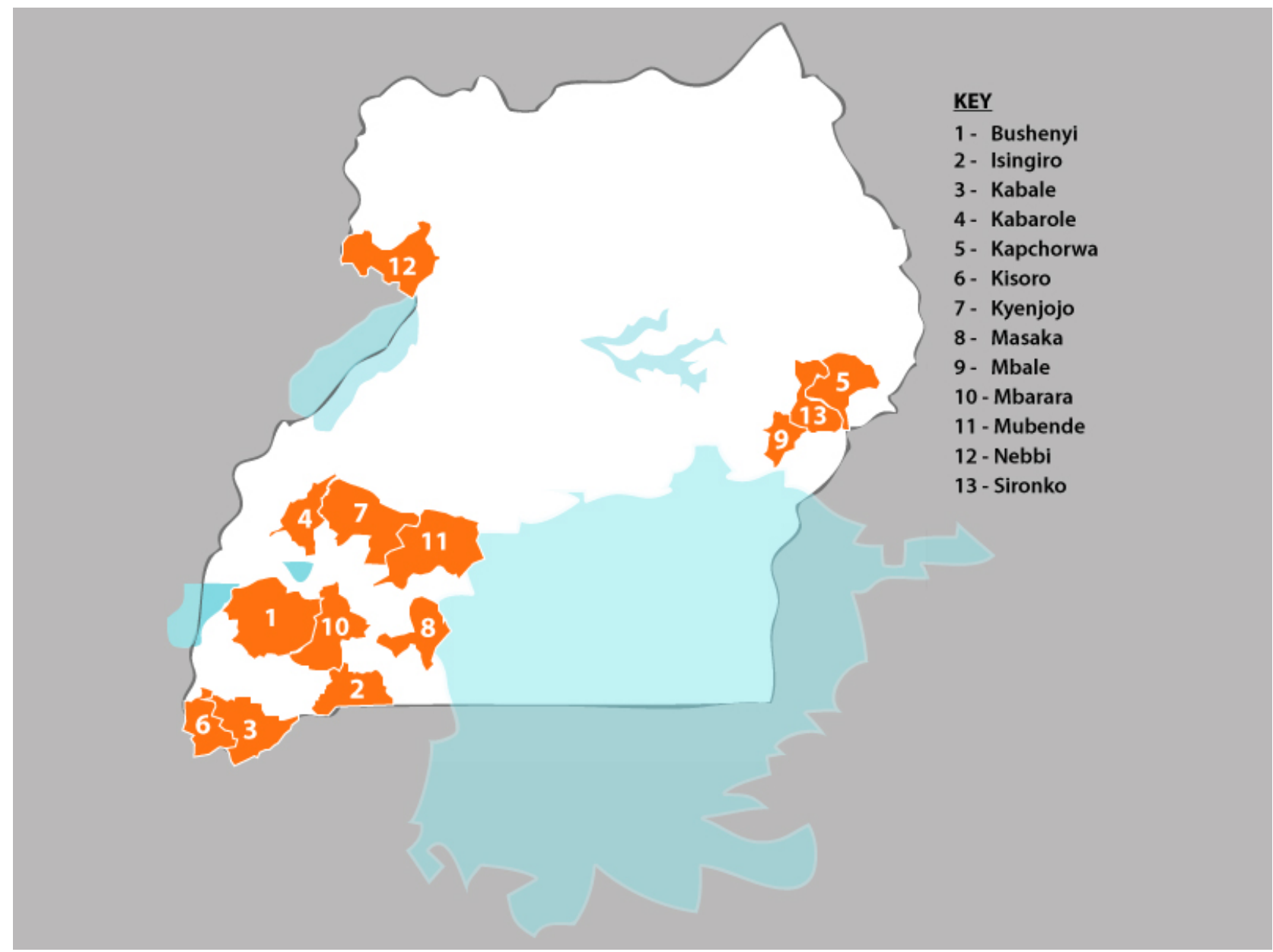

Source: Okwadi J., 2013 
The CGIAR Research Program on Roots, Tubers and Bananas (RTB) is a

Roots, Tubers and Bananas

partnership collaboration led by the International Potato Center implemented

jointly with the Alliance of Bioversity International and the International Center

for Tropical Agriculture (CIAT), the International Institute of Tropical Agriculture

(IITA), and the Centre de Coopération Internationale en Recherche Agronomique

pour le Développement (CIRAD), that includes a growing number of research

and development partners. RTB brings together research on its mandate crops:

bananas and plantains, cassava, potato, sweetpotato, yams, and minor roots and

tubers, to improve nutrition and food security and foster greater gender equity

especially among some of the world's poorest and most vulnerable populations.

www.rtb.cgiar.org

Alliance

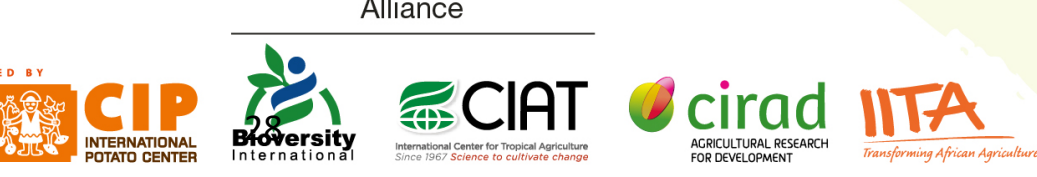

